\title{
Liminal geopolitics: the subjectivity and spatiality of diplomacy at
}

\section{the margins}

\section{Fiona McConnell}

Forthcoming: Transactions of the Institute of British Geographers

It's a sunny afternoon in July and dozens of smartly dressed delegates are streaming out of an imposing early-20 $0^{\text {th }}$ century building in central Brussels. They have spent several hours delivering reports on human rights situations, proposing motions on self-determination and electing their Presidency. On the steps of the building business cards are exchanged, hands shaken and photographs taken beside a series of national flags. But this is not a conventional meeting of members of the diplomatic corps. The flags on display are not ones seen flying outside UN buildings nor on the pages of school atlases. These 'diplomats' do not have recognised status under the Vienna Convention, and the building that these delegates have been using is not theirs. Rather, it houses the Flemish Parliament and, as today is a Saturday, the place is otherwise deserted. ${ }^{1}$

\section{Introduction}

We are living in a period when the world of diplomacy - once seen as the last bastion of stability and stasis in international politics - is widely understood to be changing, and changing fast. On the one hand, members of the diplomatic corps are increasingly having to diversify their knowledge and practices: they are now routinely tasked with engaging with foreign publics; there is a rapid speeding-up of diplomacy in an era of instantaneous communication; and state diplomats are increasingly called upon to step beyond their

\footnotetext{
${ }^{1}$ Field-diary, 4 July 2015.
} 
traditional remit and engage in humanitarian crises and environmental issues. On the other hand, there has been a proliferation of 'new' actors in the diplomatic field working in parallel to, in partnership with or in competition with state diplomats. These include supranational and subnational diplomatic services (e.g. the EU’s External Action Service (EEAS) and the international relations of regions and cities, respectively), and the engagement of multinational corporations, international NGOs and unrecognised states in different modes of diplomacy. As Merje Kuus has recently noted, accounts of these trends present a picture of diplomacy as increasingly sped up, ‘open, networked and flexible’ (2016, 41).

Scholarship in international relations (IR) and, to a lesser extent, political geography has started to address these trends and to ask how the multiplication of actors might be changing the nature and quality of diplomacy (Cooper and Hocking 2000; Dittmer and McConnell 2016; Sending et al 2011). This is a rich body of research but it remains premised on a problematic binary of 'old diplomacy', as exemplified by state actors and the status quo, being threatened and reconfigured by 'new diplomacy', heralded by non-state actors. In contrast this paper adopts a different starting point, promotes a novel conceptual approach and draws on new empirics. The vignette above describes the XII General Assembly of the Unrepresented Nations and Peoples Organisation (UNPO), a coalition of almost 50 stateless nations, indigenous communities and national minorities which are currently denied a place at international diplomatic forums. The delegations - which include those from Aceh, East Turkestan, Somaliland and Balochistan - are definitively outside the official diplomatic corps, but this does not stop them actively replicating UN structures and mimicking the protocols of formal state diplomacy. This paper asks how we can make sense of such juxtapositions of formal/informal, official/unofficial, inside/outside in the realm of diplomacy without reproducing binaries of old order/new order, state/non-state. As such, I am interested in what happens at the boundary, the threshold. How can we get a handle on the inherent 
ambiguities, ambivalences and dynamism of such a parallel system of inter(non)state diplomacy? What might such a perspective on diplomacy mean for understandings of who is, and who should be, a legitimate actor in international relations? And how can we think differently about the norms and stability of the inter-state system and the possibilities of transformation?

The field of critical geopolitics is, in many ways, in an ideal position to address these questions. From its outset this body of scholarship has sought to unsettle the central position occupied by the state in traditional political geography and IR writing and has directly challenged 'conventional demarcations of foreign and domestic, political and non-political, state and non-state’ (Dodds, Kuus and Sharp 2013, 7). In recent years feminist contributions to critical geopolitics have argued for the need to engage with a range of intertwined scales in our accounts of geopolitical subjectivity, including the everyday and the body (e.g. Hyndman 2004), and the notion of subaltern geopolitics has been promoted to take non-Western geopolitical practices and traditions seriously (Sharp 2011). However none of these approaches within critical geopolitics have provided the analytical tools to effectively examine the dynamism, ambiguities and creativity that define subject positions and spatialities that are at the threshold of conventional geopolitical categories. In looking elsewhere for a more apposite conceptual tool I turn to the notion of liminality as developed in cultural anthropology. This is a concept which has been surprisingly overlooked in political geography and, as such, this paper asks how geographers might engage more productively with it, particularly in light of emergent work in political anthropology and critical IR on liminality as a paradigm for understanding stability and change in institutionalised orders (e.g. Horvath et al 2015; Bátora and Hynek 2014).

Empirically this paper focuses on the articulation of liminal political subjectivities and spatialities through the lens of the UNPO. A unique umbrella organisation of polities 
excluded from but aspiring to engage with the formal state system the UNPO provides training in lobbying and diplomacy, and facilitates engagement of its members with UN bodies and the European Parliament. In the sections that follow I analyse not only the mechanisms by which these liminal geopolitical actors have been excluded from the modern diplomatic order, but also how they have sought to carve out subject positions, repertoires of practice and alternative spaces of diplomacy which embrace inbetweenness, processuality and ambivalence. The following section reviews literature on marginality and subalternity in critical geopolitics, sketches out the genealogy of the idea of liminality and examines how this concept has been engaged with in critical IR scholarship. The empirical lens of the UNPO and its members is then used to explore three areas of geopolitical enquiry that the notion of liminality opens up. First is the spatiality of diplomacy in terms of the out-ofplaceness of liminal actors as well as the construction of transformative spaces of quasiofficial diplomacy. Second are particular qualities of political subjectivity, including the blurring of boundaries between diplomacy and activism, and the notion of geopolitical shapeshifters, with liminal actors drawing on ambivalent positionalities to leverage diplomatic access. Finally attention turns to the notion of communitas to draw out the politics of belonging, recognition and legitimacy, and the paper concludes by considering the wider implications of 'liminal geopolitics'.

\section{Conceptualising the margins of geopolitics}

Geographers have long been drawn to the marginal, the exceptional and the transgressive. This has ranged from early interests in the seemingly untapped economic and (geo)political potential of exotic marginal lands (Driver 2001) to scholarship on marginalised individuals, groups and spaces (Cresswell 1996; Diener and Hagen 2010) and marginality being understood as both a position of subjugation (Dennis 2006) and of resistance (hooks 1990). 
Within critical geopolitics the notion of marginality has been taken up by feminist scholars who have challenged the masculinism of geopolitics (Dowler and Sharp 2001; Hyndman 2004), work on anti- and alter-geopolitics which contests the state-centrism of the field (Routledge 1998; Koopman 2011) and, more recently, scholarship promoting the idea of 'subaltern geopolitics’ (Sharp 2011, 2013; Sidaway 2012). This latter extension of the concept of critical geopolitics is based on the appraisal that, certainly until recent years, most scholarship in this field has focused empirically on the European and North American centres of geopolitics. Not only does such a fixation with the 'great powers' ignore geopolitical narratives emerging from the majority world, it also means that critical geopolitics has remained a largely western way of seeing and knowing (Toal 2003).

In her delineation of 'subaltern geopolitics’, Joanne Sharp draws on Mohammed Ayoob's (2002) work on subaltern realism in order to turn attention to neglected traditions of geopolitical thinking. As such, subaltern geopolitics is a framing to explore how political actors outside the main power centres do not simply bear witness to dominant geopolitical discourses, but also produce their own narratives (Harker 2011; Woon 2011). With its postcolonial emphasis the notion of subaltern geopolitics therefore brings to the fore 'the voices of those usually rendered marginal and silent in other accounts' and is a call for critical geopolitics to 'find space for this subaltern agency, to reverse the gaze, to look back' (Sharp 2011, 271, 272). The notion of subalternity has two particular resonances with the case of the UNPO and its members. First, it brings to the fore the power relations that underpin the positionality of these actors within the modern diplomatic system. Premised on a social context of hierarchy and structural violence, subalternity provides a useful lens for examining asymmetrical power relations and the politics of resistance against hegemonic geopolitical configurations. Second, Sharp's focus on to the original military meaning of the subaltern as a subject position which is 'neither the commander, nor outside of the ranks' 
$(2013,22)$ presents it as an ambiguous subject position of marginality 'that refuses to be seen purely as the "Other”' (Woon 2011, 286). This has distinct resonances with the modes of diplomatic subjectivity of the UNPO and its members: they are politically excluded from hegemonic power structures in international politics, they are often formally denied a voice in diplomatic forums, and yet they are not fully outside of, or other to, the interstate system. Echoing Ruth Cragg’s (2014) work on national elites representing marginalised polities, representatives of UNPO members are predominantly members of diasporas based in the West, many are professionals, and a number have held or continue to hold significant political posts in their communities by virtue of their experiences, qualifications or family connections.

Yet both of these productive insights that subalternity offers also come with drawbacks. Despite Sharp’s nuanced interpretation of the subaltern as an inbetween subject position, it is a term which continues to carry with it attributes of voicelessness and subjugation. As such, it is a descriptor which does not entirely ring true for the diplomats I have been working with, or the UNPO itself, as a key part of the organisation's remit is precisely to facilitate the voice, representation and access of its members.The notion of the subaltern also does not do justice to the intriguing temporalities, socialities and spatialities of diplomacy on the margins. Given the structural power relations that underpin it, there is arguably a stasis to the notion of the subaltern: a neatness and an implied order. As such it does not give us a sufficient handle on situations of change and uncertainty, and polities in transition.

It is with these limitations of subaltern geopolitics in mind that I turn to the notion of liminality. Both popular culture and the social sciences have, in recent years, been entranced with the concept of liminality with it being invoked to describe situations from natural disasters to transgender identities, cyborgs to airports and hotels. The etymology of 
liminality can be traced to the terms 'limen' and 'limes'. The former is a Latin term signifying a threshold that needs to be crossed while the latter was the name given to the Roman Empire’s northern border: a frontier between the civilised and the barbarians. Drawing on these definitions, the notion of liminality was originally theorised by ethnographer and folklorist Arnold van Gennep in his 1909 text Rites of Passage. In analysing initiation rituals, van Gennep identified liminality as a transitory state of inbetweenness which occurs after separation and the removal of social status, and before reincorporation into society with a new status. The notion of liminality was further developed by cultural anthropologist Victor Turner in the 1960s. The focus of Turner's work was 'liminal personae', individuals who undergo liminal experiences and are thereby inherently ambiguous. As such, Turner presents liminality as a condition 'neither here nor there, betwixt and between the positions assigned and arrayed by law, custom, convention and ceremonial' $(1969,95)$. However, Turner's focus on personal transformations during rites of passage meant that his work was restricted to the scale of individuals and small-scale societies, and was largely apolitical as it narrowly focused on liminality as a category of cultural experience. Efforts to scale up the notion of liminality and trace the role of liminal moments in socio-political transformations were first initiated by Shmuel Eisenstadt (1985) through his work on comparative liminality. The ‘travelling’ of this concept to disciplines beyond anthropology has been further promoted in recent years, with, for example, Horvath, Thomassen and Wydra (2015) arguing that liminality has the potential to be a 'master concept' for understanding transformations in our rapidly globalising world at a range of scales.

Given the spatial dynamics of liminality - including the territorial component of rites of passage - it is perhaps surprising that the concept has not received more analytical attention within the discipline of geography. Where the concept has gained some traction is in 
social and cultural geography. Following the pioneering work by Rob Shields (1990) on liminal spaces this has included work on the landscapes of Christian pilgrimage (Maddrell and della Dora 2013), the coexistence of cyberspace and geographical space (Madge and O’Connor 2005) and Elizabeth Teather's (1999) edited volume on the spatialities of life transitions. Within political geography there has been little discussion of the concept of liminality and, where the term has been used, for example in Bronwyn Wood's work on young people’s everyday politics (2012), John Agnew on Hebridean identity (1996), and Lerna Yanik on Turkish exceptionalism (2011) there has often been little engagement with Turner and van Gennep’s scholarship.

This relative neglect of liminality in political geography is in contrast to cognate disciplines such as IR and political science. Empirically scholarship in these fields has focused on the role of peripheral states which fit neither the categories of 'self' nor 'other' in narratives of European identity, including work on the discursive construction of Turkish ‘exceptionalism' (Rumelili 2003) and the position of Eastern European states in the context of EU enlargement (Mälksoo 2012). Beyond the European context scholars have turned attention to Australia as a liminal geopolitical actor (Higgot and Nossal 1997), humanitarian aid work as a liminal rite of passage (Smirl 2012) and the liminality of post-communist transitions (Horvath 2009). However, as IR scholar Maria Mälksoo notes, there is considerable unrealised potential for the application of liminality across a range of problems in international politics, from core concepts of sovereignty and security to analysis of 'structural transformation of the international system, extraordinary politics at times of transition and the constitution of political identities’ (2012, 481). Enthusiasm around liminality in critical IR is grounded not just in the empirical questions that it offers insights into: liminality is also seen as a framing which shakes up epistemological assumptions by 
disrupting the essentialised binaries of centre/periphery and domestic/international (Walker 1993) and facilitating a nuanced and plural conceptualisation of political subjectivity.

What might be a radical epistemological departure for IR has arguably been at the very core of critical geopolitics since its inception in the 1990s (Dalby 1991). However, where critical geopolitics has struggled somewhat is in capturing the dynamism of political subject formation and the 'messiness' of geopolitical relations. Whilst the notion of the subaltern starts to push in this direction, I want to suggest that the notion of liminality both complements and extends an analysis that is attuned to the contingencies, plurality and creativity of geopolitics. As noted above, the concepts of the subaltern and the liminal have significant points of intersection around ambiguous subject positions, yet they have discrete disciplinary genealogies and literature that draws on one rarely if ever mentions the other. In what follows I argue that, whilst subalternity has much to offer analysis of structural power relations, liminality provides insights into three hitherto neglected dynamics. First, with its roots in cultural experience and social change, liminality brings to the fore the processual nature of geopolitics and thereby has the potential to offer a more nuanced understanding of transformation, emergence and becoming within the international system. As such, this highlights both the relationality of power and the temporal dynamics of international politics, with liminal sites, actors and moments being understood as representing times of change and transformation, and also sites generative of prefigurative politics (Vasudevan 2015). Second, and relatedly, liminality as a threshold situation produces intense creativity and thus shines a light on practices of innovation, political renewal and aspiration (Wilson and McConnell 2015). For Turner, such creativity meant that liminality had emancipatory qualities. This is a normative move that Homi Bhabha (1994) underlined in his understanding of hybridity as a strategy of resistance and liberation which takes place in liminal spaces. However, as per critiques of this normative agenda of hybridity (Mitchell 1997), just as creativity does not 
automatically lead to emancipation so liminality is not necessarily 'something simply to be celebrated .... Quite the contrary: liminality needs to be duly and carefully problematized' (Thomassen 2014, 8).This observation leads to the third dynamic that liminality offers insights into: that of ambivalence. With liminality leading to 'ambiguity, paradox and confusion' (Turner 1967, 96-97) there is an unease and unsettling-ness at the core of liminality. It is this broader sense of unease which, I argue in this paper, should be embraced in critical geopolitics.

\section{Liminal diplomacy: the case of the UNPO}

Attending to the rise of non-state actors on the diplomatic stage has been a growing body of work loosely grouped under the heading of 'new diplomacy' (Riordan 2003). This includes research on NGO diplomacy (Betsill and Corell 2008), indigenous diplomacy (Beier 2010), the EEAS (Kuus 2014) and paradiplomacy (Aldecoa and Keating 1999; Cornago 2010). The notion of liminality has gained surprisingly little traction within this field of critical diplomacy studies. One notable exception is Jozef Bátora and Nik Hynek’s examination of how three 'fringe players’ - the Holy See, Sovereign Military Order of Malta and EU 'challenge established dominant conventional notions about how actors within the diplomatic order act' $(2014,82)$. Whilst offering a fascinating account of the nature of stability and change in modern diplomacy their study is based on a rather narrow reading of liminality which fails to meaningfully engage with anthropological interpretations of the term. In developing a more attentive engagement with liminality and seeking to avoid the pitfall of 'singling out one set of actors, and hanging the causal story on their doings' (Sending et al 2011, 541), my approach is not to use liminal diplomacy as a category of actors per se but rather to attend to the qualities and dynamics of liminality as set out above. My focus is thus on the subjectivity and experiences of actors which exist 'betwixt and between' state and 
non-state categories, and on liminal diplomatic spaces that they engage with and that they construct.

As Hamilton and Langhorne note, the “"non-state actor” is a new name for a not so very new phenomenon in international politics' $(1995,242)$ with aspirant states, exiled governments, indigenous communities and political dissidents having long sought to cultivate foreign relations through engaging in formal diplomatic practices. In the contemporary period the likes of Palestine, Taiwan, Somaliland and Western Sahara invest in diplomatic missions of various kinds, lobby UN bodies, and petition the governments of states which are perceived to hold clout internationally. However, at the same time, these polities face significant barriers to engaging in with an international system that actively seeks to exclude and silence actors deemed to challenge the territorial integrity of existing states. In addition, and with distinct similarities to nascent post-colonial states in the midtwentieth century (Shimazu 2014), these polities lack economic resources (to build and maintain embassies and to send their diplomatic staff around the world), they often lack human resources (many have small populations) and those without a tradition of formal diplomacy may lack knowledge of how international diplomacy works. The UNPO was established, in part, in order to respond to the latter of these challenges.

Launched in 1991 at the Peace Palace in The Hague the UNPO is an umbrella organisation of almost 50 indigenous, minority and occupied peoples which, due to their lack of legal recognition, are formally excluded from the conventional fora of international politics which are mandated to protect human rights and address conflict. Based out of offices in The Hague and Brussels, the UNPO provides advocacy training, organises fact-finding missions to Member areas to monitor elections and situations of political tension, and facilitates engagement of these communities with UN bodies, the European Parliament and national governments. The organisation is modestly funded through annual membership fees 
alongside grants from international foundations and occasional subsidies from sympathetic governments. The research that underpins this paper is based on a series of interviews with members of the UNPO Presidency, Secretariat staff (past and present) and leaders from a range of member communities, as well as textual analysis of UNPO working papers, press releases and training guidelines. Participant observation was also undertaken at two UNPO trainings events and four conferences held between 2012 and 2015, its General Assemblies in 2012 and 2015 and the 2014 Presidency meeting. In the following sections of this paper I use the empirical lens of the UNPO and its members to explore three areas of geopolitical enquiry that the notion of liminality opens up.

\section{Liminal spatialities and diplomatic out of placeness}

There is an inherent spatiality to the concept of liminality. Not only did the term originally mean a 'stone placed at the threshold of a door that physically had to be mounted to cross from one space to the other' (Szakolczai 2015, 23), but both van Gennep and Turner conceptualised liminality as being underpinned by spatial as well as social transitions. Yet, despite spatiality being a logical point of departure for analyses of liminality, in extant scholarship spatial dimensions are often deemed difficult to pin down and are thus overlooked. Attending to the spatiality of diplomacy can offer a way to ground the notion of liminality as diplomatic sites are in many ways quintessential liminal spaces. United Nations buildings are designated spaces of political neutrality, embassies are places of extraterritoriality and all diplomatic sites, from conference venues to ministerial offices and even dining tables, are associated with highly ritualised behaviour (Constantinou 1998; Craggs 2014; Neumann 2013). Yet, as I set out in this section, attending to the margins of such liminal diplomatic sites can offer further insights into the simultaneously symbolic and quotidian nature of diplomatic practice. 
For many minority communities obtaining UN observer accreditation is increasingly difficult due to a series of blocking tactics used by powerful UN member states. Yet civil society actors do get access to specific arenas ‘inside’ international diplomacy, for example organising side events at UN meetings and submitting shadow reports to UN treaty bodies. Moreover, UN and state diplomats often seek to meet with representatives from unrecognised states and minority communities, in many cases because there is a genuine interest in what is happening on the ground in conflict situations where non-state actors are key interlocutors. Yet, as my respondents noted, such meetings happen in a series of liminal spaces at the edge of official diplomacy: spaces which are deliberately off-site and disconnected from the symbols of state power. Representatives of exile Assyrian organisations described themselves as 'hanging out' in cafes and hotel lobbies in and around UN meetings in Geneva, hoping to catch a word with passing diplomats sympathetic to their cause. Meanwhile Nagorno Karabakh diplomats spoke positively of their elected President occasionally meeting with foreign ministry officials, but noted that these meetings have routinely been in restaurants and hotels, not in government buildings.

At first glance the deliberate exclusion of unrecognised diplomats - often individuals who are democratically elected - from the classic spaces of state diplomacy is significant. The symbolism of where meetings are held, hands are shaken and photographs are taken matter. Whilst these spatial exclusions are far from acts of direct oppression, there are nevertheless resonances with Oren Yiftachel's (2009) notion of 'gray spacing': the practice of indefinitely positioning populations between legality and illegality. What we see here is a positioning of these not-quite-state actors somewhere between full UN membership and being beyond the pale. The liminal spaces that they are relegated to are spaces produced by social relations which bypass the dichotomies of official and unofficial, formal and informal. 
These are also spaces which highlight the absurd within international diplomacy. As Philip Smith has noted:

'liminal spaces are created by narratives of absurdity, and are sustained by quasiritualised carnivalesque, playful or grotesque forms of behaviour. These narratives disrupt traditional categories of thought and morality. They are often either ludic in character, or absurd in the sense that they are fragmented and defy any easy classification or ontological grounding except that they are "other” to the everyday' $(1999,20)$

In order not to 'upset' Chinese diplomats, meetings between world leaders and the exile Tibetan spiritual leader the Dalai Lama in recent years have not only been held secretly - in the crypt of St Paul's cathedral in the case of British Prime Minister David Cameron's meeting in 2012 - but have also included farcical moments, with His Holiness being ushered out the back door of the White House, past the rubbish bins, after meeting President Obama in 2010. The experiences of liminal diplomatic actors also foreground absurd moments within the UN system. As a representative of the Uighur community recounted to me: 'you have these crazy times at the Human Rights Council when you have to get there really early and then you have to run to secure your chair in the queue so that you are able to get in as an NGO. You are watching for the guys from the Chinese or the Cuban state 'NGOs' and you are trying to run against them so that you secure your place.’

Such 'narratives of absurdity' are far more significant than mere anecdotes. They offer a valuable insight into the norms and power relations that underpin the hegemonic system of international diplomacy. As noted above, the notion of liminality may have less to say about structural power and violence than the concept of subalternity, but its association with the 
absurd offers a novel and revealing perspective on the relative power and position of geopolitical actors.

At the same time as traditional spaces of diplomacy are closed off to such liminal geopolitical actors, we also see the construction of alternative spaces of quasi-official diplomacy. Indeed, the rationale for establishing the UNPO was to 'fill a gap' left by the existing international system; a gap 'created by the de jure requirement of recognised statehood in order to participate in international decision-making fora' (Van Walt van Praag 1995, 305). In more practical terms, we can think of a range of sites of alternative diplomacy. These include the sets of rooms in key national capitals which, though legally unrecognised, claim to be embassies of stateless nations (McConnell et al 2012), and the Aboriginal Tent Embassy, established in 1972 in front of Parliament House, Canberra, as part of a claim that, since Aboriginal people were effectively aliens in their own land, they needed an embassy to represent their interests to the Australian state (Foley et al 2013).

In the case of the UNPO its most important diplomatic spaces are its General Assemblies. Held every 18 months these events are not only where the organisation elects its leadership and discusses its long-term strategies, but they are also opportunities to rehearse diplomatic protocol. A range of locations have been used depending on budgetary constraints and the availability of willing hosts. These include the Italian Parliament chamber, meeting rooms in Geneva, and, the Flemish Parliament in Brussels (as noted at the start of this paper). During these two-day events delegations of UNPO members present updates on their situations, table propositions and collectively draft a general resolution. Delegates are seated in concentric horse-shoes of desks, with their polity's name cards on proud display. National flags adorn the walls and there is enthusiastic lobbying for Presidency positions followed by a bewilderingly complicated voting system. ${ }^{2}$

\footnotetext{
2 The UNPO’s Presidency is effectively an elected executive committee comprising representatives from nine Members, and a President and
} Vice-President. 
With this emulation of the UN system these General Assemblies are rehearsal spaces (McConnell 2016). They are sites where UNPO members can try out being diplomats, become familiar with the spaces of national parliaments and practice lobbying skills. But more than this, they are fundamentally transformative spaces, where we can see the ‘emergence of new subjectivities through the production of space’ (Yiftachel 2009, 247). They are spaces where normality is suspended: spaces where individuals are transformed into delegates, equals, decision-makers, recognised members. ${ }^{3}$ After the Assembly these diplomats go back to their day jobs but their confidence as representatives and the legitimacy of their national cause has been bolstered. The suspension of disbelief in these spaces is also attributable to the fact that the UNPO and its members do not quite belong there. The idea of being 'out of place' (Cresswell 1996) - of actions transgressing the social norms of particular spaces - has been well documented in geographical scholarship, but the scene sketched out at the start of this paper was not a situation of diplomatic disobedience. The UNPO had applied for and been granted permission to use rooms in the Flemish Parliament and the security guards at reception were polite and efficient at checking everyone through, albeit bemused at some of the national dresses on display. Yet, at the same time, being in a building on a Saturday which, during weekdays is a bustling workplace, did feel strange. This was very much borrowed space. Not clandestine as such, but there was a feeling of not wanting to tread on the toes of those with a legitimate right to the spaces of legislative decision-making. No food was allowed in the meeting room, and the staff cafeteria was shut, so lunch was taken milling around with sandwiches outside the front entrance. As one delegate joked 'the UNPO, we are often times kept outside, on the street!'

\section{Geopolitical shapeshifters: blurring boundaries of political subjectivity}

\footnotetext{
${ }^{3}$ Whilst attendance at UNPO General Assemblies, conferences and trainings can be understood as a form of professional development and they are certainly sociable networking events, there is not an additional profit-driven agenda. Conversely, for Member representatives UNPO activities and lobbying itself brings with it a not insignificant financial burden, including taking unpaid leave.
} 
If the spaces which the UNPO creates can be understood as transformative of political subjectivities then the question arises as to the nature of the 'actorness' (Hocking 1999) of this organisation and its members. Labels and categories have proved to be vexed issues for those involved with, or who seek to write about, geopolitical actors such as those which are members of the UNPO. Not only are UNPO members an eclectic mix of exile governments, stateless nations, de facto states, minority communities and indigenous polities, but most descriptors that are in common use are problematic in one way or another. Using terms which include a negative prefix - unrecognised states, unrepresented peoples, non-states - can problematically infer subscription to the existence of a zero-sum-game of sovereign statehood. Meanwhile the label 'subaltern', as noted above, implies a position of relative powerlessness which is not always borne out in reality. A similar critique can be made of the term marginal, a notion which can also lead to something of an analytical dead end because it always implies a centre from which the margin is distant and different. Not only does the notion of liminality eschew such binaries but it turns attention precisely to boundary positions and subjectivities defined by inbetweeness. It is a notion which thereby shifts our attention away from labels and categories and towards particular qualities of political subjectivity that are acute in the polities being discussed here, but which also have broader resonances. In this and the following section I tease out a series of these qualities that the lens of liminality and the case of the UNPO bring to the fore: inbetweenness and ambiguity, becoming and transition, belonging and a sense of communitas.

A recurrent theme in interviews with representatives of UNPO members was their uncertainty as to how their role should be described, both to their own communities and to wider audiences with whom they were seeking to engage. As was the case for many diplomats and political leaders from postcolonial states in the mid-twentieth century and postcommunist states in more recent decades, a number of these individuals were, in previous 
'careers', resistance fighters, pro-independence rebels or human rights activists. Not only is this therefore a case where the concept of mimicry proves productive (see McConnell et al 2012), but the career biographies of these individuals raise the question of where the boundary lies between a 'diplomat' - a bona fide representative and a professional negotiator - and an 'activist' - someone advocating change through campaigning.

This is a distinction which comes into sharp relief at unexpected moments. Figure 1 is a photograph of UNPO members who attended - and in a number of cases spoke at - a conference on human rights hosted by the European Free Alliance at the European Parliament. Earlier that day the delegates had all been signed into the parliament building by MEPs, and were in smart attire - both western suits and national dress - with security clearance badges still on display. However no sooner had they posed for this photograph with their national flags than the parliament security guards came over and threatened to call the police and have the delegates escorted off the premises. The sight of flags from disputed territories - including Aceh, West Papua, Brittany and the Chittagong Hill Tracts - led the security officials to believe that this was an unauthorised protest by activists making a stand for secession.

The recounting of this incident is not to assert that these individuals are not activists. Many of those in this photograph deploy a range of political tactics in order to raise awareness of the situation that their community faces and to leverage international support, including street protests, vigils, boycotts and petitions. Indeed many individuals I spoke to described their negotiation of dual roles of diplomat and activist as wearing two hats, with the activist one often being more comfortable - a more 'natural fit' - than the diplomat one. However, what is striking about this group photograph is that this is a moment in which these individuals have sought to dress, act and speak like diplomats precisely in a setting where such comportment is the norm, but these performances and practices have not been read as 
'diplomatic'. Resonating with Georg Simmel’s notion of the stranger, these individuals are, through the display of the symbols of their nations, perceived to not belong in this space of international diplomacy, to bring 'qualities into it that are not, and cannot be, indigenous to it' (1908 in Levine 1971, 143). Whilst the presence of the UNPO delegates on the steps of the European Parliament is not deliberately provocative, it nevertheless is read as unsettling the norms of behaviour in this space. These are liminal subjects on the threshold of a key institution of diplomacy and, as such, a sense of uneasiness is created in the eyes of those whose job is to maintain the perceived status quo. The presence of this delegation therefore exposes taken for granted activities and unsettles distinctions between 'what is diplomatic activity and what is not, and who, therefore, are diplomats and who are not' (Hamilton and Langhorne 1995, 3).

The notions of inbetweenness and ambiguity also define the UNPO itself. While its members might be understood as existing somewhere between states and non-states and their representatives somewhere between diplomats and activists, the UNPO can be seen as occupying a grey zone between an NGO and an international organisation (IO). It is registered as a Stichting (foundation) in the Netherlands and, at first glance, its day-to-day activities resemble those of a campaigning NGO, with crowdfunding campaigns for development projects in member communities and demonstrations outside national parliaments. However, its establishment as a membership organisation, its covenant, governance structures (General Secretary, Presidency and Secretariat) as well as its formal systems of rules and procedures means that it has more in common with IOs than NGOs. Indeed its emulation and mimicry of the practices and procedures of the UN itself is striking and deliberate. The UNPO in many ways acts as an agent of socialisation for its members (e.g. Gheciu 2005), coaching them in the mores and language of diplomacy through its training events and the rehearsal of diplomatic protocols at its General Assemblies. 
In light of these threshold subject positions, I want to suggest that the notion of geopolitical shapeshifters is useful in this case. In the first instance I am cautious about attaching a concept-metaphor to these polities and the UNPO itself. Plenty abound in the literature on liminality, from Turner's notion of the trickster to van Gennep’s understanding of a passenger within a transitional phase, Simmel's sociological notion of the stranger and even Haraway's concept of the monster (1992). ${ }^{4}$ Each of these metaphors does useful work in highlighting particular qualities of political subjectivity vis-à-vis liminal geopolitics mimesis, hybridity, ambiguity- but there is the danger that attention gets drawn to the 'baggage' that these metaphors bring. In light of this I use the notion of shapeshifter loosely: as a descriptor rather than a category or fixed label. What it brings to the fore is the fact that these geopolitical actors - representatives of 'unrepresented' polities, and the UNPO itself look different at different times and in different settings. Neither 'self' (state/IO) nor 'other' (non-state/NGO), they occupy an in-between position, but this is not a static or fixed status. There is an inherent dynamism in being able to emulate a state diplomat or an international organisation at certain periods and enact practices more conventionally associated with political activists and campaigning NGOs in other times and spaces. And this is a dynamism that can, in many cases, be productive. Member representatives and UNPO officials I have spoken to are generally not troubled by the slippage between diplomacy and activism. Rather they embrace it, and the liminal subjectivity that negotiating such a threshold enables. This has distinct resonances with Bátora and Hynek’s reflections on the positionality of 'fringe' diplomatic players:

Adaptation, strategic realignment and institutional mimicry all allow fringe players to look similar to states proper. Yet... they further cultivate their distinctness and maintain traditions... their fringe position in the international system allows such

\footnotetext{
${ }^{4}$ Christian Bueger and Francesca Dickson organised a fascinating workshop on the 'Diplomacy of Monsters' at the University of Cardiff in
} May 2014 which focused on a range of unofficial diplomats. 
actors to be more flexible and innovative as they can also draw on and utilize structures, environments and/or practices from different institutional orders (2014, 77).

In the context of the UNPO and its members, being able to draw upon political repertoires from diplomacy and from activism opens up valuable opportunities. For example the UNPO organises a series of conferences each year at the European Parliament, as side events at the UN in Geneva or at parliaments in Western states. Focused on a particular member or on cross-cutting themes such as contemporary slavery or minority language rights, these are information-sharing events where member representatives and human rights experts give presentations to an audience which includes invited politicians and policy-makers. At first glance such events could be organised by a number of human rights focused NGOs. Yet there is always an extra dimension of diplomatic creativity. This might be UNPO Presidency members using their speeches to make direct appeals to audience members as was the case at a conference on religious minorities at the Bavarian Parliament in 2014 when a Green Party MP was petitioned to speak out on the Uighur issue in advance of the German Chancellor's visit to China. Or the UNPO’s General Secretary using his ‘closing remarks’ slot to read out a prepared declaration on behalf of the conference rather than a summary of what has been said. The declaration made at the end of a conference on the future of Balochistan held in London in 2013 urged 'the international community to work towards a genuine dialogue concerning the resolution of Baloch-Pakistan conflict and the implementation of the Baloch right of self-determination’ and was subsequently issued as a press release. ${ }^{5}$ As such, the UNPO is both a hybrid actor and an organisation that is more than an NGO or international organisation: it is an organisation which capitalises on an excess of political tactics.

\footnotetext{
${ }^{5}$ www.unpo.org/downloads/605.pdf
} 
Such embracing of inbetweenness with regards to political status thereby opens up diplomatic opportunities that are closed to those who have been assigned more fixed political categories. Self-identified political activists rarely gain entry into the forums of international diplomacy and formal state diplomats run into trouble when they become 'too activist' as the case of the former British Ambassador to Uzbekistan Craig Murray attests (Murray 2006). However ambivalence in the realm of political subjectivity can also have drawbacks. Performing with sufficient diplomatic decorum in international forums can often mean stripping out the passion, emotions and overt nationalism from a community’s narrative. Graphic pictures of torture of prisoners might be an effective campaign tool on a street protest or in appeal letters to supporters, but it is often counter-productive to the cause when lobbying at the UN. Likewise emotional speeches highlighting human rights atrocities or passionately promoting nationalism can, at best, fall on deaf ears to international audiences grown blasé to tales of woe or, at worst, can dissuade diplomats from offering support due to fears of upsetting other member states. Yet, not only is the translation of narratives into the cadences of international diplomacy a skill which takes investments in time and expertise to master, but it can also feel like self-censorship and even a betrayal to the cause.

\section{Communitas and the politics of belonging, recognition and legitimacy}

'we are family here in the UNPO - we have many differences but we also have the basis of mutual respect. I like to say that we share the same pillow, even if we have different dreams’ (former UNPO Secretary General, June 2014)

Alongside highlighting the ambivalence and inbetweenness of (geo)political subjectivities, liminality also offers valuable insights into 'the dynamics of the politics of belonging, becoming and recognition’ (Mälksoo 2012, 483). Underpinning this is the notion of 
communitas. Originally a Latin term which refers to the spirit of community, Turner conceptualised communitas as a shared experience of equality which emerges through people experiencing liminality together (1974, 76-83). In denoting the creation of strong bonds between individuals at particular times, despite their social differences in the pre- and postliminal states, the notion of communitas has striking resonances with the UNPO. At first glance the list of UNPO members appear to be unlikely bedfellows. Not only do they span all continents but they cover a wide constitutional spectrum, with their political demands ranging from full recognition of statehood (e.g. Somaliland), through to claims to self-determination (e.g. Iranian Kurdistan) and demands for the protection of cultural rights (e.g. Afrikaners). They are a group of polities which would likely not, under other circumstances, share a lobbying platform. Yet they have come together through a series of shared experiences of disadvantage and marginality: exclusion from forums of international diplomacy, and common struggles to protect human rights. This 'family’ who 'share the same pillow' has also been fostered through a series of 'rites of passage'.

The most important of these rites of passage is the signing of the UNPO's covenant by new members. Reflecting the role of European international lawyers in helping to establish the organisation, the principles which members are required to demonstrate and abide by include adherence to human rights standards and the principles of democratic pluralism, the promotion of nonviolence and respect for the right to self-determination. ${ }^{6}$ Prospective members apply to the UNPO Presidency who consider the applications at their bi-annual meetings. An assessment is made of whether the applicant meets the UNPO's criteria, and whether the organisation is truly representative of their community, nation or people. If accepted, the new members are formally admitted during the following General Assembly. This is a formal affair, with representatives of the new member coming to the

${ }^{6}$ These membership criteria mean that some polities which might be expected to be members (e.g. Palestine, Western Sahara) are not part of the UNPO 'family'. 
front of the Assembly, signing a copy of the UNPO's covenant, shaking hands with the President and exchanging their national flag for a UNPO flag.

In many ways this ceremonial entry into the UNPO family has resonances with diplomacy more generally. The identity of the diplomatic corps is formed through the diplomatic act with the representation of diplomacy creating a politico-social group through flags, conferences and shared protocols. In the case of the membership rituals of the UNPO we also see an intense feeling of social togetherness and the creation of a level playing field amongst actors of varying sizes, resources and political clout. Whilst nationalism underpins the politics of most of the member communities, within UNPO events this is tempered by a collective pan-community solidarity. More precisely it is a sense of communitas which, in creating an 'inside' on the outside of international diplomacy, fosters belonging, recognition and legitimacy. Indeed the construction of political legitimacy underpins the relationship between the UNPO and its members. On the one hand UNPO gains legitimacy from its members: 'As emphasized in its Covenant, UNPO is not an organization for unrepresented peoples; it is an organization of these peoples' (UNPO 2011, 12, emphasis added). Yet this also creates vulnerability, as one 'rogue' member has the potential to discredit the entire organisation and its membership. As a former UNPO Secretariat member put it:

The success of the UNPO is due to the legitimacy of members - their goals and cases and causes. But of course also there is the difficulty with members. We have the guidelines for membership and the Presidency checks every application, and in the beginning we were more flexible with accepting members - everyone was welcome! But then we had some problems and had to be more strict. Some members make the whole organisation ridiculous and in some cases we had to expel them, like if they had corruption or turned to violence, or had some strange goals (November 2012) 
Indeed with the fear of the organisation being deemed 'ridiculous' we again see the power of narratives of absurdity that underpin liminal situations, and the power relations within the UNPO in its efforts to police membership are thereby exposed.

On the other hand member polities gain legitimacy from the credibility of UNPO as a 'known' organisation at the UN, one that has received international recognition for its work and that can provide a neutral forum for dialogue. ${ }^{7}$ As Michael van Walt van Praag, one of the initiators of the organisation, has stated:

Whereas some governments and intergovernmental organisations are unwilling to meet with representatives of movements that are not internationally recognised or that oppose governments with whom they maintain relations, they may well be in a position to meet with representatives of UNPO or with representatives of those same movements within the context of UNPO (1993, 324).

As well as gaining legitimacy and representation through the UNPO, membership itself is also transformative as it constitutes a form of recognition. By becoming a UNPO member a polity transitions from a political status of 'unrecognised' to being recognised as the rightful representative of their community by their peers. Indeed the notion of transition is at the core of the UNPO's raison d'être as all members are demanding a change in their current circumstances. Put crudely, the aim of the members is to no longer be members and the aim of the organisation is to not have to exist. There is a teleology of sorts to these prolonged transitions. Whilst some members are expelled for reneging on commitments to non-violence or no longer representing their community, others have 'graduated' from the organisation after securing independence and UN membership (e.g. Estonia, Timor-Leste). Indeed, this progression to incorporation into the society of states was framed by my respondents both through the notion of maturity and an expectation (not always met) that those who had

\footnotetext{
${ }^{7}$ The UNPO has been awarded the Tolerance Award (1991), Social Innovation Award (1992), Petra Kelly Peace Award (1998) and was nominated for the Nobel Peace Prize in 1993.
} 
succeeded in achieving such a sought after status would act paternally to remaining UNPO members through financial support and political leverage.

If we are to scale up the notion of transformation then the question arises as to how transformative the UNPO and its members are in relation to the 'new diplomacy'. As one of the founding members noted, the organisation was initially seen as potentially unsettling to the international order, but this 'threat' soon dissipated:

...when we started there was resistance from many places, politically it was so sensitive, the issues that we were putting on the table. Governments they were reluctant, they felt threatened. They were asking themselves, "what was this organisation of secessionists coming together!?” Especially the Western governments, they saw our members and their flags and they turned away - they didn’t want to see or acknowledge these issues of self-determination and minority rights. But after two or three years we were part of the diplomatic corps so to say in The Hague... we were more accepted all round. Politicians, governments, diplomats in Geneva, they started to know the genuineness of our goal... that we were a facilitator role, not threatening to them. So after these few years we became a normal organisation in the eyes of the UN in Geneva and many diplomats there, they were used to our presence, to us being around in the UN buildings. (October 2012)

The ‘normalisation' and increasing acceptance of the UNPO, helped in no small part due to its promotion of non-violence and democracy and its explicit intention not to create an alliance against established states, should not necessarily be read as a sign that the systemic norms of international diplomacy have shifted. Rather, with their mimicry of UN membership systems and bureaucratic procedures this grouping of non-state polities arguably replicates and reinforces rather than transforms the interstate system. Such a reading is a useful antidote to the over-hyping of the newness of changes in the international system. The old order has 
far from disappeared. As Rob Walker (1993) has argued, there has always been dynamism in the international system, and the current order is remarkably stable and adaptive.

But dismissing the UNPO as not being transformative of international diplomacy misses the subtleties of what is going on here. Again the notion of liminality offers a useful conceptual lens. For if we see the UNPO as both a means to an end (international recognition) and an end in itself (a parallel system) then there is ambivalence to its transformative capacities. In terms of the former the UNPO is an interlocutor and gatekeeper, socialising its members in the mores of international diplomacy, fostering legitimacy and facilitating their access to key forums. With regards the latter the UNPO has created an alternative family of nations, constituted of places and peoples not represented on conventional political maps, which fosters solidary and, through filling a gap in the international system, seeks to make it more just. There is thus a tension at the core of the UNPO: between mimicry of the interstate system and forging a different path. As per Turner (1969), the UNPO as a liminal actor can be seen as the carrier of an anti-system within the modern diplomatic order. But, as Bátora and Hynek note, 'seeds of anti-systems do not necessarily need to mean a systemic challenge, or ontological subversion.... [rather] they can contribute to deepened and reinforced legitimacy of a particular order' $(2014,81)$. Here, the UNPO seeks to exist as an idealised version of the current system. Democracy, non-violence and human rights might be principles which underpin the UN system, but, as noted above, the UNPO actually enforces these as membership criteria.

\section{Conclusion: the creative ambivalence of liminal geopolitics}

As I have sought to outline in this paper, the liminal geopolitical actors that are the UNPO and its members are not political 'others' to conventional diplomacy, but at the same time they are also experimenting with and adapting culturally specific modes of statecraft. They 
are both inside and outside the international system, making use of borrowed meeting places and occupying liminal subject positions between political activist and official diplomat. Whilst the actual membership of the UNPO might be small, it is emblematic of a not insignificant geopolitical constituency. A statistic that Erkin Alptekin, a veteran Uighur activist and one of the 'founding fathers' of the UNPO quotes is that there are 6,500 peoples, nations and ethnic groups in the world of which less than 200 are represented in the UN. By focusing our academic attention primarily on states and international organisations we miss the inherent complexity and diversity of geopolitical subjectivity, practice and discourse. In order to appreciate this diversity without being overwhelmed by it, I want to suggest that the lens of liminality is one that has the potential to enrich scholarship in critical geopolitics. Like subaltern geopolitics, the notion of liminal geopolitics is partly a call to look to the margins of geopolitics: to take seriously the practices, discourses and experiences beyond the core arenas of international politics. Yet, with the idea of ambivalence underpinning it, liminality infers conflation of peripherality with neither subjugation nor with emancipation. Indeed, as feminist scholars have noted,ambivalence is an under-rated but vital quality in critical scholarship (Bondi 2004, Rose 1993). As discussed above, it underpins the hesitancy and disquiet which should accompany any moves to celebrate marginalised voices in critical geopolitics (Ó Tuathail 1996, 256). As such, it should be embraced as an opportunity for considered reflection on the nature and the future (re)configuration of political space and authority more generally.

Liminality is also a provocation to take process, creativity and aspiration seriously. As I have outlined in this paper, the notion of liminal geopolitics offers particularly astute insights into the nature and dynamics of political subjectivity - including the processes by which geopolitical categories and actors are produced - and the spatiality and temporality of geopolitical becoming, belonging and recognition. In troubling the stasis of political 
subjectivity liminality is a concept which raises the question of who is, and who should be, a legitimate actor in international relations. Liminality therefore facilitates a more plural and open conceptualisation of who the practitioners of geopolitics are and how their practices produce particular spatial relations. It is also a concept that brings to the fore the relational and processual nature of international politics in ways that acknowledge the entangled nature and asymmetrical power configurations of geopolitical relations (Sending et al 2011, Sharp et al 2000).

Finally, in exploring the dynamics of 'liminal geopolitics' I am cautious about adding yet another prefix in what is already a crowded domain. The proliferation of subsets of critical geopolitics arguably creates a confusing muddle of research trajectories rather than leading to further clarity (Ciută and Klinke 2010). As such, my aim is not for liminal geopolitics to replace or supplant subaltern, anti or alter geopolitics. Rather it is a provocation to establish a dialogue between the anthropological notion of liminality and more established theoretical groundings of postcolonialism, feminism and post-structuralism in political geography and, in the process, to think more carefully and imaginatively about political subjectivity, spatiality and transition. Moreover, turning attention to the concept of liminality vis-à-vis critical geopolitics extends our gaze beyond the disciplines that have, to date, been sources of inspiration and dialogue. Spurred on by the recent anthropological turns in critical IR and diplomacy theory, perhaps it is time that critical geopolitics, and political geography more generally, turned more meaningfully to concepts and debates in political anthropology. To date there has been a surprising lack of engagement beyond an embrace of aspects of each other's approaches, with a turn towards ethnography in political geography (e.g. Megoran 2006), and increasing engagement with questions of spatiality in political anthropology (e.g. Ferguson and Gupta 2002). The concept of liminality could provide a more sustained framework for active intellectual exchange with anthropology and with disciplines to which 
liminality has already 'travelled'. As such, liminality not only has the potential to open up new fields of intellectual enquiry but it also promotes polyvocality in the politics of critical geopolitics.

\section{References}

John A 1996, Liminal Travellers: Hebrideans at Home and Away Scotlands 3: 31-42

Aldecoa F and Keating M eds 1999 Paradiplomacy in Action: The Foreign Relations of Subnational Governments. Frank Cass, Portland

Ayoob M 2002 Inequality and theorizing in International Relations: the case for subaltern realism. International Studies Review 4: 27-48

Bátora J and Hynek N 2014 Fringe Players and the Diplomatic Order: The 'New' Heteronomy. Palgrave Macmillan, London

Beier JM ed 2010 Indigenous Diplomacies. Palgrave Macmillan, Basingstoke Betsill MM and Corell E eds 2008 NGO diplomacy: the influence of nongovernmental organizations in international environmental negotiations. MIT Press, Cambridge, MA Bhabha H 1994 The Location of Culture. Routledge, London

Bondi L 2004 10th Anniversary Address For a Feminist Geography of Ambivalence. Gender, Place \& Culture 11(1): 3-15.

Ciută F and Klinke I 2010 Lost in conceptualization: reading the "new Cold War" with critical geopolitics. Political Geography 29: 323-32

Constantinou CM 1996 On the Way to Diplomacy. University of Minnesota Press, Minneapolis

Constantinou CM 1998 Before the Summit: Representations of Sovereignty on the Himalayas. Millennium: Journal of International Studies 27: 23-53 
Cooper AF and Hocking B 2000 Governments, Nongovernmental Organisations and the Re-calibration of Diplomacy. Global Society 14: 361-76

Cornago N 2010 On the Normalization of Sub-State Diplomacy. The Hague Journal of Diplomacy 5: 11-36

Craggs R 2014 Postcolonial geographies, decolonization, and the performance of geopolitics at Commonwealth conferences. Singapore Journal of Tropical Geography 35: 39-55 Cresswell T 1996 In Place/Out of Place: Geography, Ideology and Transgression. University of Minnesota Press, Minneapolis

Dalby S 1991 Critical Geopolitics: Discourse, Difference and Dissent. Environment and Planning D: Society and Space 9: 261-83

Dennis RM ed 2006 Marginality, Power and Social Structure. JAI Press, London Diener AC and Hagen J eds 2010 Borderlines and Borderlands: Political Oddities at the Edge of the Nation-State. Rowman \& Littlefield, Lanham

Dittmer J and McConnell F eds 2016 Diplomatic Cultures and International Politics: Translations, Spaces and Alternatives. Routledge, Abingdon

Dodds K, Kuus M and Sharp J eds 2013 Companion to Critical Geopolitics. Ashgate, Farnham

Dowler L and Sharp J 2001 A Feminist Geopolitics? Space and Polity 5: 165-76

Driver F 2001 Geography Militant: Cultures of Exploration and Empire. Wiley-Blackwell, Oxford

Eisenstadt SN 1985 Comparative liminality: Liminality and dynamics of civilization. Religion 15: 315-38

Ferguson J and Gupta A 2002 Spatializing States: Toward and Ethnography of Neoliberal Governmentality. American Ethnologist 29: 981-1002 
Foley G, Schaap A and Howell E eds 2013 The Aboriginal Tent Embassy: Sovereignty, Black Power, Land Rights and the State. Routledge, London

Gheciu A 2005 NATO in the 'New Europe'. Stanford University Press, Berkeley Hamilton K and Langhorne R 1995 The Practice of Diplomacy: its evolution, theory and administration. Routledge, London

Harker C 2011 Geopolitics and family in Palestine. Geoforum 42: 306-15

Harraway D 1992 The Promises of Monsters: A Regenerative Politics for Inappropriate/d Others. in Grossberg L, Nelson C and Treichler P eds Cultural Studies, New York 295-337 Higgott RA and Nossal KR 1997 The International Politics of Liminality: Relocating Australia in the Asia Pacific. Australian Journal of Political Science 32: 169-86

Hocking B 1999 Patrolling the 'Frontier': Globalization, Localization and the 'Actorness' of Non-Central Governments. in Aldecoa F and Keating M eds Paradiplomacy in Action: The Foreign Relations of Subnational Governments. Frank Cass, Portland 17-39

Horvath A 2009 Liminality and the unreal class of the image-making craft: An Essay on Political Alchemy. International Political Anthropology 2: 51-73

Horvath A, Thomassen B and Wydra H eds 2015 Breaking boundaries: varieties of liminality. Berghan, Oxford

Hyndman J 2004 Mind the Gap: Bridging Feminist and Political Geography through Geopolitics. Political Geography 23: 307-22

Koopman S 2011 Alter-geopolitics: Other securities are happening. Geoforum 42: 274-84 Kuus M 2014 Geopolitics and Expertise: Knowledge and Authority in European Diplomacy. Wiley, Oxford

Kuus M 2016 Diplomacy and audit: Technologies of knowledge in Europe. Geoforum 68: 39-47 
Levine DN 1971 Georg Simmel: On Individuality and Social Forms. University of Chicago Press, Chicago

Maddrell A and della Dora V 2013 Crossing surfaces in search of the holy: Landscape and liminality in contemporary Christian pilgrimage. Environment and Planning A 45: 1105-26 Madge C and O'Connor H 2005 Mothers in the making? Exploring liminality in cyber/space. Transactions of the Institute of British Geographers 30: 83-97

Mälksoo M 2012 The challenge of liminality for International Relations theory. Review of International Studies 38: 481-94

McConnell F 2016 Rehearsing the State: The political practices of the Tibetan Governmentin-Exile Wiley, Oxford.

McConnell F, Moreau T and Dittmer J 2012 Mimicking state diplomacy: The legitimizing strategies of unofficial diplomacies. Geoforum 43: 804-14

Megoran N 2006 For Ethnography in Political Geography: Experiencing and Re-imagining Ferghana Valley Boundary Closures. Political Geography 25: 622-40

Mitchell K 1997 Different Diasporas and the Hype of Hybridity. Environment and Planning D: Society and Space 15: 533-53

Murray C 2006 Murder in Samarkand: a British ambassador's controversial defiance of tyranny in the war on terror. Mainstream Publishing, London

Neumann IB 2013 Diplomatic sites: a critical enquiry. Hurst, London

Ó Tuathail G 1996 Critical Geopolitics: The Politics of Writing Global Space. Routledge, London

Riordan S 2003 The New Diplomacy. Polity Press, Cambridge Rose G 1993 Feminism and Geography: The limits of geographical knowledge. Cambridge, Polity Press. 
Routledge P 1998 Anti-geopolitics: introduction. In G Ó Tuathail, S Dalby, and P

Routledge eds The geopolitics reader. London, Routledge

Rumelili B 2003 Liminality and Perpetuation of Conflicts: Turkish-Greek Relations in the context of community building by the EU. European Journal of International Relations 9:

213-248

Sending OJ, Pouliot V and Neumann IB 2011 The future of diplomacy: Changing practices, evolving relationships. International Journal 66: 527-42

Sharp J 2011 Editorial: Subaltern Geopolitics. Geoforum 42: 271-273

Sharp J 2013 Geopolitics at the margins? Reconsidering genealogies of critical geopolitics. Political Geography 37: 20-9

Sharp J, Routledge P, Philo C and Paddison R 2000 Entanglements of Power: Geographies of Dominance/ Resistance. Routledge, London

Shields R 1990 Places on the Margin: Alternative Geographies of Modernity. Routledge, London

Shimazu N 2014 Diplomacy As Theatre: Staging the Bandung Conference of 1955. Modern Asian Studies 48: 225-52

Sidaway JD 2012 Subaltern geopolitics: Libya in the mirror of Europe. The Geographical Journal 178: 296-301

Smirl L 2012 The state we are(n’t) in. Liminal subjectivity in aid worker auto-biographies. in Bliesemann de Guevara B ed The Political Sociology of Intervention. Routledge, London $230-45$

Smith P 1999 The Elementary Forms of Place and Their Transformations: A Durkheimian Model. Qualitative Sociology 22: 13-36 
Szakolczai A 2015 Liminality and Experience: Structuring transitory situations and transformative events. in Horvath A, Thomassen B and Wydra $\mathbf{H}$ eds Breaking boundaries: varieties of liminality. Berghan, Oxford 11-38

Teather EK ed 1999 Embodied geographies: spaces, bodies and rites of passage. Routledge, London

Thomassen B 2014 Liminality and the Modern: Living Through the In-Between. Ashgate, Farnham

Toal G 2003 Re-asserting the regional: political geography and geopolitics in a world thinly known. Political Geography 22: 653-655

Turner V 1967 The Forest of Symbols: Aspects of Ndembu Ritual. Cornell University Press, Ithaca

Turner V 1969 The Ritual Process: Structure and Anti-structure. Aldine, Chicago Turner V 1974 Dramas, Fields, and Metaphors: Symbolic Action in Human Society. Cornell University Press, Ithaca, NY

UNPO 2011 UNPO 20th Anniversary Publication: Twenty Years of Promoting Nonviolence, Human Rights, and Self Determination. UNPO, The Hague van Gennep A 1909 The rites of passage. Routledge, London van Walt van Praag M 1993 The position of UNPO in the international legal order. in Brölmann C, Lefeber $\mathbf{R}$ and Zieck $\mathbf{M}$ eds Peoples and minorities in international law Martinus Nijhoff, Dordrecht 313-29

van Walt van Praag M 1995 East Timor and the international legal order: role of the UNPO. in IPJET C ed International Law and the Question of East Timor. Russell Press, Nottingham 299-308

Vasudevan A 2015 The autonomous city: Towards a critical geography of occupation. Progress in Human Geography 39: 316-37 
Walker RJB 1993 Inside/Outside: International Relations as Political Theory. Cambridge University Press, Cambridge

Wilson A and McConnell F 2015 Constructing legitimacy without legality in long term exile: Comparing Western Sahara and Tibet. Geoforum 66: 203-14

Wood BE 2012 Crafted within liminal spaces: Young people’s everyday politics. Political Geography 31: 337-46

Woon CY 2011 Undoing violence, unbounding precarity: Beyond the frames of terror in the Philippines. Geoforum 42: 285-96

Yanık LK 2011 Constructing Turkish “exceptionalism”: Discourses of liminality and hybridity in post-Cold War Turkish foreign policy Political Geography 30: 80-9

Yitfachel O 2009 Critical theory and 'gray space’: Mobilization of the colonized. City 13: 246-63 